\title{
Access to Quality Education -A Case Study of Physically Challenged Elementary School Students of District Ganderbal (India)
}

\author{
Arsheed AhMad Paray ${ }^{1 ;}$ Dr. MOHAMmad SAYID BHAT \\ Ph. D SCHOlar Central University OF Kashmir ${ }^{1}$; AsSistant \\ ProfessorCentraluniversity OF KASHMIR ${ }^{2}$ \\ arshidparay10@gmail.com ${ }^{\text {l; DSAYEED3@GMAIL.COM }}{ }^{2}$ \\ DOI<10.26821/IJSRC.8.10.2020.81011>
}

\begin{abstract}
The present study is intended to find the influence of Quality of Education with special reference to physically challenged students of District Ganderbal. Population survey was made by the investigator to locate the physically challenged children in education Zone Ganderbal. 247 students (physically challenged) were found in the current population survey and all of them have been included in the sample. Selfconstructed information blank was employed to identify the population of physically challenged students.Quality education questionnaire developed by investigator was administered to collect the required data for the present study. Percentage staticswas employed as a statistical treatment. The results highlighted that the physically challenged students have access to low quality education at elementary level. The educational standardwith which World Health Organization ensures to provide for physically challenged students is lacking at the gross root level. It is the need of the hour that the government should take due interest in this area. The research in this area should be done on priority basis and more evaluative studies should be conducted so that we keep eye on the implementation part of the various policies at national as well as at international level.
\end{abstract}

Key words: Quality Education; Physically Challenged Children; Elementary School Students;

\section{Introduction}

"Education is a liberating force, and in our age it is also a democratizing force, cutting across the barriers of caste and class, smoothing out inequalities imposed by birth and other circumstances.'Indira Gandhi

Education plays a very important role in the all-round development of a child. Higher the educational level better is the life standard of the individual(Sarah et al. 2016) [1]. Education provides us knowledge to explore the opportunities of survival in the world and also helps us in changing it for the betterment of the humanity. It develops in an individual a perspective of looking at life through different angles. Education helps in building opinions and various point of views related to life. Education makes an individual capable of interpreting things, among many. Good education doesn't mean just mugging lessons from textbooks; it is about the lessons of life.

After independence India made a constitutional commitment to provide education to all the citizens irrespective of being normal or physically challenged. From time to time lot of efforts has taken by the 
Volume 8 Issue 10 October 2020

government in order to achieve the goal of univerlisation of elementary education. So from time to time government framed many policies, and schemes, passed many laws to help in achieving its goal. India has achieved lot of success in in this direction but lot needs to be done. The Census 2011 reveals that India's literacy level has reached up to $74.04 \% .93 \%$ of the habitations have school within the radius of $3 \mathrm{kms}$ (Census 2011) [2]. The tremendous growth of the education during the last decade has adversely affected the quality of education at elementary level.(Leu and Price-Rom 2006)[3].

Quality education is one of the important issues of the modern world. Everything needs quality in the modern competitive era so is the education. Without quality education is of no use. There arelot of parameters through which the quality of the education can be assessed.

Defining quality education, in UN sustainable development summit 2015 New York by ACCD writes we must ensures to develop an educationa system that should develop a child to reach their full potential and enter in to the society as a full and productive citizen. A quality education is one that focuses on the all-round development of a childphysical, mental, social, emotional and cognitive development, without any discrimination of caste color, socio-economic status or geographical location. It prepares a child for life (UNSDC, 2015) [4].

The quality education makes available the resources and directs the policy to ensure that a child enters the school healthy and learns the practices of healthy life style and in an environment that is safe (physically and emotionally) for the students, has access to personalized learning, supported by qualified teachers and is prepared for success and participation in global society. The quality education provides everything to the learner needed for the prosperity of the individual, communities and societies. It is in accordance with the needs and demands of the society and has access to the range of services to support the educational development of the students.

We can say that quality education is an inclusive education structured in such a waythat has ability to realize the potential of every child irrespective of the location or socio-economic status.

The quality education is based on three basic pillars

I. Access to quality teachers.

II. Access to quality learning and professional development

III. Safe and supportive learning environment The government of India has launched so many schemes to ensure the quality of education at primary level.

Initiatives by the govt. for enhancing quality of education

1. Samagra Skiksha Abhiyan (2018-19): the objective of Samagra SkikshaAbhiyan was to enhance the access to Education, promote equity and improve the quality of education by proving good quality in service training to teachers. This scheme focuses on improvement of quality of education by providing quality in-service training of teachers, heads of the institutions, conduct fixed time achievement surveys at state and national level to know the developments in different aspects of quality education.(MHRD, 2018)[5]

\section{Amendment of Right to Education Act-} 2009, (2017): the amendment to RTE came into force 20th of February 2017 to include reference on class wise, subject wise learning outcomes which can act as a benchmark for student capabilities to be achieved in each class and subject. 
Volume 8 Issue 10 October 2020

3. Rashtriya Aavishkar Abhiyan (2015): the scheme Rashtriya Aavishkar Abhiyan tries to motivate the children in the age group of 6-18 for subjects of science, mathematics and technology to be studied through most comprehensive methods like observation, experimentation, model buildings, inference drawing etc.

4. The National Council for Education Research and Training (NECRT) has developed framework for elementary school teachers for accessing their performance through constructive feedback mechanism in order to increase the accountability and enhance the performance of teachers.

5. Right to Education Act-2009: this act came into effect from Ist April 2010. The act ensures different standards to enhance the quality of education at different levels. The main thus tares of the act was pupil teacher ratio, school working days, teacher working hours, training of teachers, building and infrastructure etc.

There are also so many indicators through which the quality of education can be judged but the investigator has included only three dimensions in his questionnaire in order to have an in-depth study in the required area. The investigator has prepared the questionnaire assessing quality of education through three dimensions viz. infrastructure facilities, teaching learning material and classroom practices and learner's assessment and outcome.

\section{Need and Importance}

Education plays a very important role in enhancing the life standard of the individuals. Higher the educational status, higher is the life standard of an individual(Eric

A. Hanushek and LudgerWobmann 2007[5]). In all the societies, children need to be given opportunities to learn irrespective of being normal or physically challenged. In a legitimate effort to achieve this goal, different types of schools-normal schools special schools etc. have come into being over a period of time. Our country has long back set an objective of universalization of elementary education. To keep this objective in view, the physically challenged students cannot be ignored; they too are an important and essential componentof society that need to be addressed/educated equally to make this objective a fact. The investigator after going through a lot of review of literature,the researcher has found that the research on the physically challenged children has not been done on priority basis and so far no study has been conducted on access to quality education of physically challenged students, which prompts the researcher to explore the unbeaten area. The research has been supported by the studies conducted

\section{byAtandaSambo 2016[6].}

\section{Sample}

Population survey was made by the investigator in all the four educational zones to locate the physically challenged children in district Ganderbal. 247 physically challenged students were found in the current population survey at elementary stage and all of them were selected by the investigator for the present study. The investigator prepared the information to locate the physically challenged students for the present study.

\section{Tools used}

For the present study Information Blank was employed by the investigator to locate the population of physically challenged children and Access to Quality education questionnaire developed by Arsheed Ahmad (2020) was administered strictly according to the Manual of the scale to collect the date on Access to Quality Education. There are three dimensions in the questionnaire. There are 44 items in the test. The score 
Volume 8 Issue 10 October 2020

ranges from $0-44$. The investigator has formed three levels of the score i.e. Good, Average and Poor. The score from 0-15 is considered as poor, 115-30 as good and 30-44 as good. The respondent has to choose from the two answers either yes or no.

\section{Findings of the Study}

The investigator visited all the institutions personally and collected data on all the three dimensions of the quality education mentioned in the questionnaire:

\section{Infrastructure Facilities}

As far as the infrastructure facilities (regarding the physically challenged students) are concerned majority of the schools have scored low on quality education questionnaire. The basic facilities which a physically challenged student requireswere lacking almost in all the schools. With the unavailability of the facilities they find it hard to adjust properly, with the result they score low academics than their normal peers (Arsheed Ahmad, 2018)[7]. The school environmentis positively correlated with the academic achievement of the students (Bhat and Mir, 2018[8], Peter Barrett, 2019)[9]. None of the respondents whether head of the school, teacher, or student were satisfied with the facilities available in the school. They were of the opinion that the lack of the facilities is the most important factor for the high dropout rate of the students at elementary level. The results have been supported by the studies conducted by Latif A Choudhary, 2015[10].

\section{Teaching learning material}

The data from the schools is not satisfactory as far as the Teaching learning material is concerned.The schools did not score wellon the quality education scale and highlighted the average type of teaching learning material. The teaching learning material was outdated and was not according to the needs of the present society. The modern education system should be dynamic accepting change for the betterment of the society which is lacking in the present system of education. Thereare very good schemes as far as the elementary system of education is concerned but during the time of implementation the physically challenged students are altogether ignored it may be partially due to meager amount of funds or ignorance of the government due to lack of research in this area.So it the need of an hour that this area must be taken due of care of during research and while implementingany new policy.

\section{Learner's assessment,Evaluation and outcome}

Good assessment is necessary to know the real outcome of any educational system. Without proper assessment we can't categorize students on the basis of achievement. As for as the assessment is concerned the schools score poor on the questionnaire framed by the investigator. It should assess the whole personality of the individual. So far as the assessment process of our educational system is concerned it is outdated and mostly assess the memorization power of the students, there are other dimensions of the developmentwhich are totally ignored by the present system of assessment and evaluation. It is the need of the hour that this system must be replaced by some more efficient method which willassess all the dimensions of a child development.

\section{Discussion and conclusion of results:}

The present paper studied the access to quality education of physically challenged elementary school students of district Ganderbal. The results highlighted that the infrastructure facilities required by physically challenged students were mostly lacking in the sample schools. There are minimum basic requirements which are necessarily required by physically challenged students such as Wheel chair facility, Ramp/Rails, Rest Room, modified washroom, Scribes for 
Volume 8 Issue 10 October 2020

Examination, Braille Software/facilities, Provision of Lift (WHO 2015)[11]but most among them facilities are lacking in our schools. There are some facilities available in the schools for example washrooms, ramps, but they are not designed to cater the needs of physically challenged students. The dataalso highlightsthat private schoolstudents have access to better quality education than the government school students; they have better infrastructure facilities, dynamic and cooperative environment; also revealed by the study of Jyoti Joshi and Sunita Agarwal 2017[12]. There are almost $8-10 \%$ of the private schools which have made available all the basic requirements; providesmart classrooms facility for the students and have made the teaching learning process more attractive and dynamic. This is the main reason that the parents of the physically challenged students mostly prefer their children in private institution. The results are in line with the studies of Bernal 2005[13], Schneider et al 2014[14], and Goswami 2015[115]. The study also highlighted the teaching learning material was outdated and was not in conformity with the needs and demands of the individual and society. The teaching learning material does not motivate the students for studies which results in the drop out of these students up to the great extent as also revealed in his study by Binay Kumar Kushiyait 2011[117], B. Namunwa et al 2014[16]. The teaching learning material should be dynamic accepting change with the changing society which was altogether absent in the present educational system. While framing the curriculum all the stakeholders should be consulted and their valid viewpoints should be incorporated in the curriculum. There must be a separate department which has a close connection with the ministries of all the departments, and all the stakeholders of the society which must highlight all the potential areas so that the teaching learning material should be framed accordingly and the manpower will not be wasted by studying against the needs and demands of society. So far as the learner's assessment and evaluation is concerned the results are not satisfactory. The results of the study are in conformity with the results of the Asimchatterjee and Laxmi Rani 2013[18]. The function of the assessment and evaluation is to measure the all-round development of a child which the present evaluation system is mostly lacking. Our present day tools are mostly focused to assess the memorization power of the students and the other developmental dimensions such as reasoning, problem solving ability, leadership skills and social competence, independent thinking, which are very important for the survival of an individual in modern society and which most importantly needs to be assessed are altogether neglected. So it is the need of the hour to establish more rigorous evaluation procedure which has the power to assess the child in right way. The government should take notice in this before it is too late.

\section{Educational Implications}

Following are some of the important educational implications of the present study

1. There is no national policy for physically challenged children so there is immediate need of the hour to formulate a national policy for physically challenged children.

2. There a strong correlation between quality education on enrolment and retention of children, the authorities should take all necessary steps to make quality education a reality.

3. The authorities should make use of scholarships and other incentives to attract more physically challenged students towards schools. 
Volume 8 Issue 10 October 2020

4. There is the need of the attitudinal change in society towards physically challenged students.

5. Pass percentage should be reduced for physically challenged students in order to enhance the retention of the physically challenged students.

\section{References:}

[1] Sarah et al Effect of Education on Quality of Life and Well Being, The International Journal of Indian Psychology, 3(358), 2016, 2349-3429.

[2] Office of the Registrar General (2011). Census of India. Retrieved from http://www.censusindia.gov.in/

[3] Lue and price rom, Quality of education, a review of literature, Washington DC, institute for research, 2006.

[4] United Nations, Sustainable Development Goals. New York: United Nations, (2015).

[5] E. A. Hanushek and LudgerWobmann, The Role of Education Quality in Economic Growth, World Bank Policy Research Working Paper 4122, 2007, retrieved from

[6]S. Atanda, "Physically Challenged Students and Their Information Needs, Library Philosophy and Practice (e-journal). 1461, 2016

http://digitalcommons.unl.edu/libphilprac/1461

[7]A. Ahmad and M. S. Bhat, personality characteristics social awareness and academic achievement of the normal and physically challenged students of Kashmir, unpublished dissertation, central university of Kashmir, 2018.
[8]M.S. Bhat and S. Mir, Perceived school climate and academic achievement of secondary school students in relation to their gender and type of school, International Journal of Advanced Educational Research, 3, 2018, 620-628.

[9]P. BarrettThe impact of school infrastructure on learning: A synthesis of the evidence, Publisher: World Bank Group, ISBN: 978-1-4648-1378-8, 2019 retrieved from Barrettetal2018WBschoolreport.pdf.

[10]Latief et al, ECONOMIC effects of students' dropouts a comparative study of the causes of students' dropouts globally, conference proceeding 2015.

[11]World Health Organization (2015). Assistive Technology for Children with Disabilities: Creating Opportunities for Education, Inclusion and Participation; A discussion Paper. Geneva: WHO [12] J. Joshi and S. Agarwal, A comparative study of government and private schools for the facilities related to water hygiene, International Journal of Applied Research, 3(9), 2017, 178-182

[13] Bernal, Jose Luis.. "Parental Choice, Social Class and Market Forces: The Consequences of Privatization of Public Services in Education." Journal of

Education Policy 20 (6), 2005, 779-792

[14] Schneider, Mark, and Jack Buckley.. "What Do Parents Want from Schools? Evidence from theInternet." Educational Evaluation and Policy Analysis 24 (2), 2002, 133-144

[15] N. Goswami, Costs, Security and Discipline: Gendering the Debate on School Choice in India. Indian Journal of Gender Studies 22 (2), 2015, 243 264. 
Volume 8 Issue 10 October 2020

[16] B. Namunwa et, al., Effect of the Learning

Environment on Dropout in Primary Schools in Katilu

Division, Turkana County in Kenya, international journal of innovation research and development, 3(13), 2014, 446-452.

[17] Binay Kumar Kushiyait, School Dropout and its Relationship with Quality of Primary Education in
Nepal, the Geographical Journal of Nepal, Vol. 8, 2010-2011, 23-32.

[18] A. chatterjee and L. Rani, Present Evaluation Method of Examination: A Critical Survey, IOSR Journal of Humanities and Social Science, 11(1), 2013, 45-49. 